\title{
RASIONALISME ISLAM BERAWAL DARI BAHASA
}

\section{A. Khudori Soleh}

Dosen Fakultas Psikologi,

Universitas Islam Negeri (UIN) Malang.

Jalan Gajayana No. 50 Telepon (0341) 551354, Faksimile (0341) 572533 Malang 65144.

\begin{abstract}
It is a fact Greek philosophy has given great contribution for Islam philosophy growth. However, it does not mean that Islamic philosophy is Greek rubbing, because Islam philosophy really unlike Greek philosophy. Others, in reality, philosophy of Greek does not inspire many Islamic philosophy, moreover, majority of Islam people did not accept it. Only, some figure take and develop their philosophy based did not accept it. Only some figure and develop their philosophy based on Greek line. Sincerely, Islamic philosophy was born from thought and the treasure of Islamic science itself. It emerged from rationalization of Arab Language, then it pusped appearance rationalize of any object study, such as: jurisprudence and theology. Surely, it is triggered by existence of challenge and attacking from rationality of outside party. All have pushed all Moslem thinkers to develop rational method, and this exactly, which give road for entry of Greek philosophy in Islam society.
\end{abstract}

Key words

Rationalism, Greek philosophy, Arab Language

\section{Pendahuluan}

Beberapa peneliti Barat, seperti Renan, menyatakan bahwa Islam tidak mempunyai rasionalisme dan filsafat. Apa yang sekarang disebut 
sebagai filsafat Islam, menurutnya, bukanlah orisinil dari Islam sendiri melainkan hanya jiplakan dari filsafat Yunani, khususnya Aristoteles (384-322 SM). Sementara itu, Duhem menuduh bahwa filsafat Islam adalah nukilan dari neo-platonism (Madkur, tt:21). Yang lain menyatakan bahwa yang ada sebenarnya adalah filsafat Arab, bukan filsafat Islam, karena kebanyakan tokoh filsafat Islam adalah orang Arab.

Tulisan ini, pertama-tama, akan menanggapi tuduhan Renan dan Duhem di atas. Kedua, menunjukkan bahwa rasionalisme dan filsafat Islam bukan berasal dari Yunani -meski filsafat Yunani diakui telah memberikan kontribusi besar bagi perkembangan filsafat Islam-melainkan benar-benar dari Islam sendiri yang dimulai dari rasionalisasi bahasa. Ketiga, menunjukkan bahwa filsafat Yunani tidak diterima oleh mayoritas masyarakat Islam tetapi oleh sebagiannya, bahkan sejak awal perkembangannya dalam Islam, sehingga kita tidak dapat begitu saja menyimpulkan bahwa filsafat dan pemikiran Islam adalah copian dari Yunani.

\section{Bukan Jiplakan}

Benar bahwa pemikiran-pemikiran filsafat Yunani yang masuk dalam kancah pemikiran Islam lewat terjemahan telah mendorong perkembangan rasionalisme dan filsafat Islam menjadi makin pesat. Akan tetapi, seperti dikatakan Oliver Leaman, Louis Gardet dan al-Jabiri (Gardet, 1978:77, Al-Jabiri, 1991:57), adalah suatu kesalahan besar jika kita menganggap bahwa rasionalisme Islam dimulai dari penerjemahan teks-teks Yunani atau bahwa filsafat Islam hanya nukilan dari filsafat Aristoteles seperti dituduhkan Renan atau dari Neo-Platonisme seperti sampaikan Duhem. Pertama, bahwa belajar atau berguru tidak berarti meniru atau membebek semata. Harus dipahami bahwa kebudayaan Islam menembus berbagai macam gelombang dimana ia bergumul dan berinteraksi. Pergumulan dan intereksi ini melahirkan pemikiranpemikiran baru. Jika kebudayaan Islam terpengaruh kebudayaan Yunani, mengapa ia tidak terpengaruh oleh peradaban India dan Persia, 
misalnya? Artinya, transformasi dan peminjaman beberapa pemikiran tidak harus mengkonsekuensikan perbudakan dan penjiplakan (Madkur, tt:22).

Suatu ide dapat dibahas oleh banyak orang dan akan tampil dalam berbagai macam fenomena. Seseorang berhak mengambil sebagian gagasan orang lain tetapi itu semua tidak menghalanginya untuk menampilkan teori atau filsafatnya sendiri. Aristoteles, misalnya, jelas merupakan murid Plato (427-348 SM), tetapi ia mempunyai pandangan sendiri yang tidak dikatakan gurunya. Begitu pula Barush Spinoza (1632-1777 M) walau secara jelas sebagai pengikut Rene Descartes (1596-1650 M) tetapi ia dianggap mempunyai pandangan filosofis yang berdiri sendiri. Hal seperti itulah yang juga terjadi pada para filosof muslim. Al-Farabi (870-950 M) dan Ibn Sina (980-1037 M), misalnya, walau dianggap sebagai murid Aristoteles, tetapi ia mempunyai pandangan sendiri yang tidak sama dengan gurunya. Para filosof muslim secara umum hidup dalam lingkungan dan kondisi yang berbeda dengan filosof lainnya, sehingga adalah suatu kesalahan jika kita mengabaikan pengaruh kondisi ini dalam pemikiran dan teori mereka.

Dengan demikian, bisa dikatakan, bahwa (1) apa yang disebut transmisi filsafat Yunani ke Arab merupakan suatu proses kompleks di mana ia sering banyak dipengaruhi oleh interpretasi-interpretasi yang diberikan melalui suatu tradisi skolastik sebelumnya, dan -kadang kala - dalam istilah-istilah yang sudah digunakan secara teknis dalam disiplin baru yang berkaitan dengan bahasa Arab atau Islam. Konsekuensinya, tugas rekonstruksi sumber Yunani untuk ilmu dan filsafat tidak mungkin selalu diharapkan berbentuk suatu terjemahan yang jelas ke dalam sesuatu yang dianggap asli Yunani, tetapi harus mempertimbangkan aktivitas yang terjadi di luar teks, dan karena itu harus direkonstruksi secara terlepas dari teks. (2) Perluasan-perluasan, pengembangan dan penggarapan kembali ide-ide Yunani dari al-Kindi (801-878 M) sampai Ibn Rusyd (1126-1198 M), bahkan Suhrawardi (1153$1191 \mathrm{M}$ ) dan sesudahnya tidak mungkin sepenuhnya bisa diapresiasikan tanpa merujuk pada situasi-situasi kultural yang mengkondisikan arah 
dan karakter karya-karya tersebut. (3) Karena itu pula, presentasi karyakarya muslim secara terpisah dari faktor-faktor kultural akan menjadi suatu deskripsi yang tidak lengkap, deskripsi yang tidak bisa menjelaskan sendiri transformasi besar yang sering terjadi ketika batasbatas kultural sudah terlewati (Sabra, 1992:90). Sedemikian, sehingga tidak bisa dibantah bahwa karya-karya filsafat Islam disusun berdasarkan nilai-nilai pokok agamanya dan kondisi sosial yang melingkupinya. Artinya, filsafat Islam adalah sesuatu yang berdiri sendiri, mempunyai arah, gaya, dan persoalan sendiri, tidak sekedar peralihan dari Yunani.

Kedua, realitas yang ada menunjukkan bahwa pemikiran rasional telah dahulu mapan dalam masyarakat muslim sebelum kedatangan filsafat Yunani lewat terjemahan. Meski karya-karya Yunani mulai diterjemahkan pada masa kekuasaan Bani Umaiyah, tetapi buku-buku filsafatnya yang kemudian melahirkan filosof pertama muslim, yakni alKindi (801-873 M), baru mulai digarap secara serius pada masa dinasti Abbasiyah, khususnya pada masa al-Makmun (811-833 M) oleh orangorang seperti Yahya al-Balmaki (w. 857 M), Yuhana ibn Musyawaih dan Hunain ibn Ishaq (Hitti, 1986:363, Watt, 1992:38, Al-Ghurabi, tt:128). Pada masa-masa ini, sistem berpikir rasional telah berkembang pesat dalam masyarakat intelektual Arab-Islam, yakni dalam figh (yurisprudensi) dan kalâm (teologi). Dalam bidang fiqh, penggunaan nalar rasional dalam penggalian hukum (istinbâth) dengan istilah-istilah seperti istiḩsân, istishlâh, qiyâs dan lainnya telah lazim digunakan. Tokoh-tokoh mazhab fiqh yang menelorkan metode istinbâth dengan menggunakan rasio seperti itu, seperti Abu Hanifah (699-767 M), Malik (716-796 M), Syafi'i (767-820 M) dan Ibn Hanbal (780-855 M), hidup sebelum kedatangan filsafat Yunani. Begitu pula dalam bidang teologi. Doktrin Muktazilah yang rasional, yang dibangun Wasil ibn Atha' (699$748 \mathrm{M})$ telah mendominasi pemikiran masyarakat, bahkan menjadi doktrin resmi negara dan berkembang dalam berbagai cabang, dengan tokohnya masing-masing seperti Amr ibn Ubaid (w. 760 M), Jahiz Amr ibn Bahr (w. 808 M), Abu Hudzail ibn al-Allaf (752-849 M), Ibrahim ibn 
Sayyar an-Nadzam (801-835 M), Mu’ammar ibn Abbad (w. 835 M) dan Bisyr ibn al-Mu 'tamir (w. 840 M) (Gardet, 1978:76, Watt, 1992:41).

Semua itu menunjukkan bahwa sebelum dikenal adanya logika dan filsafat Yunani, telah muncul model pemikiran filosofis yang berjalan secara baik dalam masyarakat Islam, yakni dalam bidang teologi dan kajian hukum. Bahkan, pemikiran rasional dari teologi dan hukum inilah yang telah berjasa menyiapkan landasan bagi diterima dan berkembangnya logika dan filsafat Yunani dalam pemikiran Islam (Mahdi, 1992:56).

\section{Berawal Dari Bahasa}

Ketika dikatakan bahwa pemikiran rasional Islam tidak bersumber dari filsafat Yunani, tetapi benar-benar berdasar pada ajaranajaran pokok Islam sendiri, muncul pertanyaan, bagaimana dari pokokpokok ajaran Islam, al-Qur'an yang global dan tidak mengajarkan tata berpikir secara rinci bisa melahirkan sistem berpikir yang baik dan rasional?

Kemunculan sistem berpikir rasional dalam Islam, sebagaimana juga ditulis Lauis Gardet dan Anawati (1978:64), pertama, didorong oleh munculnya mazhab-mazhab bahasa (nahw) lantaran adanya kebutuhan untuk bisa memahami ajaran al-Qur'an secara baik dan benar. Harus dipahami, meski al-Qur'an diturunkan dalam bahasa Arab, tetapi tidak semua lafat-lafatnya bisa dengan mudah dipahami oleh orang-orang Arab sendiri saat itu. Sejak khulafa' al-Rasyidin sudah dirasakan adanya kebutuhan akan tafsir dan cara pembacaan yang 'benar'. Dengan semakin banyaknya orang non-Arab yang masuk Islam, kebutuhan tersebut semakin besar dan mendesak, dan ketika pengetahuan keagamaan mulai di dengungkan, orang-orangpun semakin merasa perlu akan adanya pembakuan aturan kebahasaan yang memungkinkan orang untuk membaca al-Qur'an secara benar, disamping untuk mengetahui kemukjizatan al-Qur'an dari segi bahasanya.

Sehubungan dengan hal itu, ada 3 (tiga) mazhab nahwu yang dikenal, yaitu: 
Pertama, Mazhab Basrah. Mazhab ini memiliki kecenderungan untuk menegakkan koordinasi rasional terhadap bahasa. Mereka juga membuat aturan-aturan umum dan menganggap tidak benar segala penyimpangan yang dilakukan terhadap aturan yang diciptakannya. Menurut sebagian orang, seperti sumber-sumber dari Syiah, mazhab ini dibangun oleh Abu Aswad al-Duwali atas nasehat Imam Ali ibn Abu Thalib ra (w. 661 M). Akan tetapi, sumber-sumber lain yang lebih menyakinkan menyatakan bahwa mazhab ini dibangun oleh Isa ibn 'Umar al-Tsaqafi (w. 766 M). Tokoh utamanya saat itu adalah Khalil, kemudian muridnya yang bernama Sibawaih (w. 793 M). Menyusul kemudian al-Asma`i (w. $830 \mathrm{M}$ ) dan Abu 'Ubaidah (825 M) yang sangat terkenal pada masa Harun al-Rasyid (785-809 M), lalu al-Mubarrad (w. 898 M), al-Sukari (w. 888 M) dan Ibn Duraid (w. 934 M) (Gardet, 1978:70, Amin, 1963:298).

Kedua, Mazhab Kufah. Madzab ini didirikan oleh al-Rasai beberapa tahun kemudian yang merupakan tandingan dari mazhab Basrah. Berbeda dengan mazhab Basrah yang bersandar pada aturan logika, mazhab Kufah justru bersandar pada sosiologi bahasa (sima $i$ ) dan lebih menekankan prinsip universal linguistik sehingga lebih bebas dalam menerima aturan yang berbeda-beda. Bahkan, bila perlu, bisa bersandar pada pemakaian-pemakaian yang tidak lazim untuk membuat aturan baru. Tokohnya yang penting adalah al-Mufadlal alDlabbi (w. 876 M), al-Kisai (w. 805 M), al-Farra (w. 822 M), Ibn al-Sikkait (w. 858 M) dan Tsa'lab (w. 904 M) (Amin, 1963:296).

Ketiga, Mazhab Baghdad. Madzhab berusaha mempertemukan perbedaan dan persaingan keras antara kedua mazhab di atas dengan cara menggabungkan dua kecenderungan yang ketat dan longgar di antaranya. Tokoh utamanya adalah Ibn Qutaibah (w. 889 M) (Gardet, 1978:70).

Perdebatan antara mazhab-mazhab nahwu tersebut memberikan pengaruh besar dalam pembacaan al-Qur'an, dan pada gilirannya, nahwu yang dielaborasi dengan cermat telah memberikan suatu bingkai dan kategori-kategori suatu kosa kata yang memberikan catatan khas 
pemikiran rasional pada fiqh dan teologi. Artinya, aturan dan logika dalam bahasa (nahw) inilah yang telah mendorong munculnya pemikiran rasional dalam bidang hukum maupun teologi pada fase-fase berikutnya, sebelum datangnya filsafat Yunani. Kenyataannya, perdebatan dalam kajian hukum dan teologi Islam juga berawal dari perdebatan tentang kosa kata dan istilah-istilah yang digunakan dalam teks suci.

Dalam bidang hukum, kajian bahasa tersebut pada gilirannya mendorong fuqaha untuk menjelaskan maksud-maksud yang diinginkan dalam teks suci. Dorongan itu semakin kuat seiring dengan adanya kebutuhan untuk menjawab problem-problem riil di masyarakat. Pada awal perkembangan Islam, ketika Rasul saw masih hidup, semua persoalan dapat diselesaikan dengan cara ditanyakan langsung pada beliau, atau diatasi lewat jalan kesepakatakan di antara para shahabat. Akan tetapi, hal itu tidak dapat lagi dilakukan setelah Rasul wafat dan persoalan-persoalan semakin banyak dan rumit seiring dengan perkembangan Islam yang demikian cepat. Jalan satu-satunya adalah kembali kepada ajaran teks suci, al-Qur’an, lewat berbagai pemahaman. Dalam hal ini, ada beberapa model kajian resmi yang nyatanya mempunyai relevansi filosofis dan rasional. Antara lain, (1) penggunaan takwîl. Makna takwil diperlukan untuk mengungkap atau menjelaskan masalah-masalah yang sedang dibahas. Meski model ini diawasi secara ketat dan terbatas, tapi pelaksanaannya jelas membutuhkan pemikiran dan perenungan mendalam, karena ia berusaha 'keluar' dari makna lahiriyah (zhahir) teks. (2) Pembedaan antara istilah-istilah atau pengertian yang mengandung lebih dari satu makna (musytarak) dengan istilah-istilah yang hanya mengandung satu arti. Di sini justru lebih mendekati model pemecahan filosofis dibanding yang pertama. (3) Penggunaan qiyâs (analogi) atas persoalan-persoalan yang tidak ada penyelesaiannya secara langsung dalam teks (Coulson, 1987:4-8). Misalnya, apakah larangan menimbun emas dan perak (QS. Al-Taubah, 34) itu hanya berlaku pada emas dan perak atau juga meliputi batu permata dan batu berharga? Apakah kata 'mukmin' dan 'muslim' dalam al-Qur'an juga mencakup wanita dan budak? 
Yang perlu dicatat dalam pertumbuhan dan perkembangan kajian hukum (figh) ini --dalam kaitannya dengan pemikiran rasional-adalah tempat yang diduduki logika dalam perdebatan-perdebatan fiqhiyah, setidaknya pada lingkungan mereka pendukung $r a^{\prime} y u$ (Garder, 1978:74), Al-Raziq, 1959:203-213). Walau logika terpusat pada qiyas dan masih sangat sederhana, akan tetapi maknanya cukup besar dalam perkembangan pemikiran rasional. Sering terjadi, sebelum menjadi seorang teolog atau filosof, yang bersangkutan adalah fâqih (ahli hukum). Ia sudah mempunyai pengalaman yang cukup banyak tentang metode perdebatan, sehingga ketika menghadapi persoalan teologis atau filsafat, kebiasaan untuk mendekatinya dengan metode perdebatan berlangsung begitu saja (Garder, 1978:71).

Sementara itu, dalam bidang teologi, kajian bahasa juga telah mendorong para teolog untuk menyelaraskan pandangan-pandangan yang tampaknya kontradiktif dan rumit untuk selanjutnya mensistematisasikannya dalam suatu gagasan metafisika yang utuh. Misalnya, bagaimana menyelaraskan antara sifat kemahakuasaan dan kemahabaikan Tuhan di satu sisi dengan sifat maha tahu-Nya atas segala tindak manusia untuk taat atau kufur untuk kemudian dibalas sesuai perbuatannya. Bagaimana juga menjelaskan secara tepat bahasabahasa antropomorfis (menyerupai sifat-sifat manusia) al-Qur`an dalam kaitannya dengan keyakinan bahwa Tuhan tidak sama dengan manusia: tidak bertangan, tidak berkaki dan seterusnya. Begitu juga dengan persoalan-persoalan teologis yang lain (Machasin, 1997).

Tuntutan-tuntutan seperti itu semakin kuat setelah umat Islam ikut terlibat dalam polemik keagamaan yang terjadi antara umat Kresten dengan Mazdiah di Damaskus. Saat itu, di Damaskus yang dijadikan ibu kota penguasa Bani Umayyah, telah terjadi polemik teologis antara umat Kresten Armenia dan Syiria dengan kaum Mazdiah, terutama mengenai masalah baik dan buruk. Dengan datangnya umat Islam berarti ada tiga pihak yang berpolemik dalam masalah ini. Menurut Yahya (Yuhana, John, Jean) ad-Dimasqi dan pengikutnya yang bernama Theodore Abu Qurra, ada 2 (dua) persoalan penting yang menjadi perdebatan pada masa itu, 
Pertama, Kebebasan dan keterpaksaan manusia. Yahya alDimasqi, seorang teolog Kristen Damaskus, menyerang umat Islam dengan pernyataan bahwa kaum muslimin menganut doktrin determinisme (jabbariyah).

Kedua, Al-Qur'an, diciptakan atau tidak. Masalah ini berawal dari persoalan mengenai logos. Dalam al-Qur'an dikatakan bahwa Isa adalah "Perkataan" (kalimah) atau "Roh" (ruh) Allah. Bagi umat Krestiani, penyebutan ini tidak menimbulkan kesulitan. "Perkataan"=logos dan "roh"=pneuma. Berdasarkan hal itu, orang Kresten menyerang umat Islam dengan pertanyaan, "Jika Isa adalah "kalimah" Allah, ia diciptakan atau tidak? Jika tidak diciptakan berarti benar bahwa Isa adalah Tuhan. Jika tidak diciptakan, Allah --sebelum Isa diciptakan - berarti tidak mempunyai perkataan dan roh (Garder, 1978:60-63).

Polemik-polemik seperti itu menggiring para intelektual muslim periode awal, khususnya para teolog, untuk berpikir rasional dan filosofis, dan kenyatannya metode-metode pemecahan yang diberikan atas masalah teologis tidak berbeda dengan model filsafat Yunani. Perbedaan di antara keduanya, menurut Leaman (Leaman, 1978:10), hanyalah terletak pada premis-premis yang digunakan, bukan pada valid tidaknya tata cara penyusunan argumen. Yakni, bahwa pemikiran teologi Islam didasarkan atas teks suci sedang filsafat Yunani didasarkan atas premis-premis logis, pasti dan baku.

\section{Filsafat Yunani}

Usaha perterjemahan buku-buku filsafat Yunani, seperti telah disinggung di atas, baru dilakukan secara serius dan besar-besaran pada masa Bani Abbas awal, yakni masa al-Ma'mun (813-833 M) (Al-Jabiri, 1991:227, Hasymi, 1975:227). Dengan usaha-usaha tersebut, logika, fisika dan metafisika Aristoteles membanjiri pemikiran kaum muslimin. Apalagi kenyataannya, saat itu, kaum muslimin lagi mabuk intelektual. Akal yang baru saja menemukan kemampuannya, memasuki persoalanpersoalan keagamaan dengan keberanian yang luar biasa, bahkan 
kadang tanpa perhitungan, setidaknya menurut kaum konservatif yang mengikatkan diri secara ketat pada al-Qur'an dan Sunnah. Yang berhasil mengarahkan kemabukan intelektual ini adalah kebutuhan akan satu tindakan yang tepat dalam menghadapi doktrin-doktrin yang --kurang lebih-- hiterodok, yang datang dari Iran, India atau daerah lain dari pinggiran Islam, seperti Mazdiah, Manikiah, materialisme dan sejenisnya, atau bahkan dari pusat Islam sendiri, sebagai akibat dari pencarian bebas yang berubah menjadi pemikiran bebas, sampai menolak otoritas wahyu atau lainnya yang dikategorikan dalam istilah 'zindiq'.

Meski demikian, perkembangan ilmu-ilmu Yunani dalam Islam berkat dukungan Khalifah tersebut bukan tanpa persoalan. Imam Ibn Hanbal (780-855 M), salah seorang imam mazhab fiqh dan orang-orang yang sepikiran dengannya dari kalangan ortodoks menunjukkan sikap yang tidak kenal kompromi terhadap ilmu-ilmu Yunani. Seperti disampaikan George N. Atiyeh, penentangan kalangan ortodoks tersebut disebabkan, pertama, adanya ketakutan dikalangan ortodoks (figh) bahwa ilmu-ilmu Yunani akan menyebabkan berkurangnya rasa hormat umat Islam terhadap Tuhan. Kedua, adanya kenyataan bahwa mayoritas dari mereka yang mempelajari filsafat dan ilmu pengetahuan Yunani adalah orang-orang non-muslim, penganut Machianisme, orangorang Sabia dan muslim penganut mazhab Batiniyah yang esoteris, yang itu semua mendorong munculnya kecurigaan atas segala kegiatan intelektual dan perenungan yang mereka lakukan. Ketiga, adanya usaha untuk melindungi umat Islam dari pengaruh Machieanisme Persia khususnya maupun paham-paham lain yang dinilai tidak sejalan dengan ajaran Islam yang ditimbulkan dari pikiran-pikiran filsafat Yunani (Atiyeh, 1983:4).

Kecurigaan dan penentangan kaum ortodoks terhadap ilmuilmu Yunani tersebut memang bukan tanpa dasar. Kenyataannya, tidak sedikit tokoh muslim yang belajar filsafat akhirnya justru meragukan dan bahkan menyerang ajaran Islam sendiri. Salah satunya adalah Ibn Rawandi (lahir 825 M) (Madkur, tt:86). Ia menolak kenabian setelah belajar filsafat. Menurutnya, prinsip kenabian bertentangan dengan akal 
sehat, begitu pula tentang syareat-syareat yang dibawanya, karena semua itu telah bisa dicapai oleh akal; akal telah mampu mengapai apa yang benar dan salah, yang baik dan jahat dan seterusnya (Madkur, $\mathrm{tt}: 86)$.

Contoh lain adalah Abu Bakar al-Razi (865-925 M) (Syarif, 1996:31-37, Arsyad, 1995:88). Al-Razi juga menolak kenabian dengan tiga alasan; (1) bahwa akal telah memadai untuk membedakan baik dan buruk, berguna dan tidak berguna. Dengan rasio manusia telah mampu mengenal Tuhan dan mengatur kehidupannya sendiri dengan baik, sehingga tidak ada gunanya seorang nabi. (2) Tidak ada pembenaran untuk pengistemewaan beberapa orang untuk membimbing yang lain, karena semua orang lahir dengan tingkat kecerdasan yang sama, hanya pengembangan dan pendidikan yang membedakan mereka, (3) bahwa ajaran para nabi ternyata berbeda. Jika benar bahwa mereka berbicara atas nama Tuhan yang sama, mestinya tidak ada perbedaan (Syarif, 1996:47, Madkur, tt:109-118, Hasan, tt:71).

Usaha penentangan kaum ortodoks yang dipelopori Ibn Hanbal terhadap ilmu-ilmu Yunani di atas mencapai puncak dan keberhasilannya pada masa khalifah al-Mutawakkil (847-861 M). Tampilnya al-Mutawakkil dengan kebijakannya yang mendukung kaum salaf menyebabkan kalangan yang tadinya tertindas ini memperoleh angin dan muncul ke permukaan menggantikan posisi orang-orang Muktazilah khususnya dan para ahli filsafat umumnya, dan mulailah terjadi "revolusi": orang-orang yang tidak sepaham dipecat dan diganti dari kalangan salaf. Al-Kindi (801-873) yang ahli filsafat adalah salah satu contoh, dipecat dari jabatannya sebagai guru istana karena berbeda paham dengan sang khalifah yang salaf (Atiyeh, 1983:7).

Setelah masa Ibn Hanbal, filsafat Yunani juga ditolak oleh alGhazali (1058-1111). Lewat karyanya yang terkenal, Tahâfut al-Falâsifah, al-Ghazali menyerang filsafat Yunani dan menyatakan bahwa beberapa di antara pemikiran metafisikanya dapat menyebabkan kekufuran, yaitu (1) pemikiran filsafat tentang keqadiman alam, (2) bahwa Tuhan tidak 
mengetahui persoalan yang partikular (juz'iyyat) dan (3) kebangkitan ruhani (Al-Ghazali, 1966;120). Serangan terhadap filsafat Yunani itu diulang kembali dalam al-Munqidz min al-Dalâl (Al-Ghazali, tt:51).

Beberapa abad kemudian, filsafat Yunani juga ditentang oleh Ibn Taimiyah (1263-1328). Ibn Taimiyah memang tidak mengkritik kajian metafisikanya seperti hal al-Ghazali, tetapi justru aspek metodologinya. Menurutnya, metode demonstrasi (burhân̂̂) yang digagas Aristoteles dan dikembangkan para tokoh filsafat Islam, penuh dengan kepalsuan dan tidak memberikan pengetahuan yang menyakinkan. Kasimpulannya hanya bersifat spekulatif (zhanni) (Soleh, 2004:219-238).

Dengan demikian, pemikiran filsafat Yunani sebenarnya tidak diterima oleh mayoritas umat Islam melainkan hanya oleh beberapa tokoh di antaranya, meski diakui bahwa pemikiran beberapa tokoh ini mempunyai gaung dan pengaruh sangat besar pada perkembangan pemikiran Islam berikutnya. Artinya, kita tidak dapat mengeneralisir dan menyimpulkan bahwa filsafat Islam adalah foto copy dari filsafat Yunani, karena masih banyak pemikiran-pemikiran filosofis lain yang justru lahir karena penentangannnya terhadap filsafat Yunani.

\section{Penutup}

Bahasa sebenarnya mempunyai peluang besar untuk menumbuhkan pemikiran-pemikiran baru di masa depan. Kenyataan sejarah juga menunjukkan bahwa bahasa telah memberikan andil besar dalam pertumbuhan pemikiran dalam Islam. Rasionalisasi bahasa telah mensponsori munculnya pemikiran rasionalisme dalam Islam. Itulah sebabnya, Naquib al-Attas, misalnya, seorang pemikir Islam kontemporer dari Malaysia menyatakan bahwa islamisasi sains harus dimulai dari islamisasi bahasa. Berawal dari islamisasi bahasa ini diharapkan akan dapat dilaksanakan islamisasi ilmu, baik dari aspek ontologis, epistemologis maupun aksiologis (Soleh, 2004:250-270).

Karena itu, kita berharap bahwa kajian-kajian bahasa di UIN dan perguruan tinggi yang lain tidak sekedar istiqamah mengikuti tradisi yang sudah ada tetapi harus dapat mencari dan memberikan alternatif- 
alternatif baru, bukan hanya dari aspek kuantitas dan fomalitasnya tetapi terlebih pada aspek kualitas dan substansialnya. Itulah tantangan Fakultas Bahasa dan Humaniora khususnya, dan orang-orang yang bergelut dalam kajian-kajian bahasa pada umumnya. $\square$

\section{DAFTAR PUSTAKA}

Al-Ghazali, Imam. Tanpa tahun. Al-Munqidz min al-Dlalâl, (ed) Musthafa Abu al-Ula. Beirut: Maktabah al-Sab 'iyah.

- 1966. Tahâfut al-Falâsifah, (ed) Sulaiman Dunya. Mesir: Dar alMa'arif.

Al-Ghurabi, Ali Musthafa. Tanpa tahun. Târikh al-Firâq al-Islami. Kairo: Maktabah Mathba 'ah.

Al-Jabiri, M. Abid. 1991. Takwîn al-Aql al-Arabi. Saudi Arabia: Markaz alTsaqafi al-Arabi. 
Al-Raziq, Mustafa Abd. 1959. Tamhîd li Târîkh al-Falsafat al-Islâmiyah. Kairo: Lajnah al-Taklif wa al-Tarjamah wa al-Nasyr.

Amin, Ahmad. 1936. Dhuhâ al-Islâm, II. Kairo: Dar al-Fikr al-Arabi.

Arsyad, Natsir. 1995. Ilmuan Muslim Sepanjang Sejarah. Jakarta:

Srigunting.

Atiyeh, George N. 1983. Al-Kindi Tokoh Filosof Muslim. Bandung: Pustaka.

Bakar, Osman. 1995. Tauhid dan Sains, terj. Yuliani. Bandung: Pustaka Hidayah.

Coulson, Noel J. 1987. Hukum Islam dalam Perspektif Sejarah. Jakarta: P3M.

Gardet, Louis and Anawati. 1978. Falsafat al-Fikr al-Dîni, II, terj. Subhi Saleh dan Farid Jabr. Bairut: Dar al-Ulum.

Hasan, Hasyim. Tanpa tahun. Al-Asâs al-Manhajiyah Libina al-Aqidah alIslâmiyah. Kairo: Dar al-Fikr.

Hasymi. 1975. Sejarah Kebudayaan Islam. Jakarta: Bulan Bintang.

Hitti, Philip K. 1986. History of The Arabs. New York: Martin Press.

Leaman, Oliver. 1988. Pengantar Filsafat Islam, terj. Amin Abdullah, Jakarta: Rajawali Pres.

Machasin. 1997. Perkembangan Teologi dalam Islam. Makalah tidak diterbitkan. Yogyakarta: Pascasarjana IAIN Sunan Kalijaga.

Madkur, Ibrahim. Tanpa tahun. Fi al-Falsafah al-Islâmiyah: Manhaj wa Tathbîquh, I. Mesir: Dar al-Ma`arif.

Mahdi, Muhsin. 1992. "Al-Farabi dan Fondasi Filsafat Islam", dalam Jurnal al-Hikmah, edisi 4 Februari.

Nasr, Husain. 1986. Tiga Pemikir Islam, terj. A. Mujahid. Bandung: Risalah.

Razi, Abu Bakar. 1973. Rasâil Falsafiyah. Beirut: Dar al-Afaq.

Sabra. 1992. "Apropriasi dan Naturalisasi Ilmu-Ilmu Yunani dalam Islam, Sebuah Pengantar", dalam Jurnal al-Hikmah, edisi 6 Oktober.

Soleh, A. Khudori. 2004. Wacana Baru Filsafat Islam. Yogyakarta: Pustaka Pelajar. 
Syarif, MM. 1996. Para Filosof Muslim, terj. Ahmad Muslim. Bandung: Mizan.

Taimiyah, Taqi al-Din Ibn. 1971. Al-Fatâwa IX. Kairo: Dar al-Kutub.

Watt, MM. 1992. Islamic Philosophy and Theology. Edinburg: Edinburg University Press. 